In north central Oxford, where most of the present science faculty buildings stand, the university has done well to buy (or to be in the process of buying) one million square feet of buildings, after the recommendation of the Holford Committee which reported in 1963. New departments of psychology and zoology are at present being built and the Radeliffe Science Library, the School of Geography and the Physics Laboratories are being extended. Since the Holford Committee sat, sixteen houses have been bought from colleges for the use of the Social Science Departments, and some of these have already moved into their new accommodation. Congregation will now have voted on the proposal to buy another nineteen houses, with 100,000 square feet, for science facilities. Despite the Government's statement of January 16, 1968, further projects may be included in the building programmes for 1970 . A new computer library will be built, and the adjacent Departments of Engineering, Survey and Geodesy and Metallurgy will be extended. The professors of these departments have already agreed to share as many facilities as possible, following the example of the zoology/psychology building, which will, the Hebdomadal Council states, guide many future developments.

\section{Reinforced Plastics}

Tise production of carbon tibre reinforced plastics (CFRP) is now going ahead even though licensing and financing arrangements between the National Rcsearch Development Corporation and the three firms involved-Courtaulds, Morganite and Rolls-Roycehave not yet been finally decided. Rolls-Royce is producing the plasties for its own use, but Courtaulds and Morganite will sell CFRP in the general market. Morganite is quoting prices of $£ 35$ per lb for batch fibre and $\$ 100$ per $1 \mathrm{~b}$ for continuous fibre, but it is acknowledged that prices will fall considerably when mass production is achieved.

The development and applications of these very strong plastics were described by Mr L. N. Phillips, head of the Plasties Technology Section, Materials Department, of the Royal Aireraft Establishment, Farnborough, at a joint session of the plastics and polymer group of the Society of Chemical Industry and the London Section of the Plastics Institute, on February 22. Mr Phillips began by pointing to the considerable experience of RAE in the development of cellulose, asbestos and glass reinforced plastics for structural purposes. The general engineering opinion was that glass fibre has too low a Young's modulus, compared with metals, to be attractive for structural purposes. Conversely, it was reasoned that a new fibre with a Young's modulus three to six times greater than glass would be of considerable interest.

Attention was focused on earbon fibres some four years ago, because of the wide difference between the properties of commercial fibres then obtainable by rayon pyrolysis (Young's modulus 6-9 million $\mathrm{lb}$ per square inch, with ultimate tensile values of 50,000 lb per square inch), and the properties of graphite whiskers (Young's modulus between 100 to 147 million lb per square inch). Details of the RAE processes for making high-strength high-modulus carbon fibres could not be given for commercial reasons, but the principle is to preserve the orientation already existing in a highly aligned textile fibre as the polymer is destroyed by heat. (The inventors are W. Watt, W. Johnson and L. N. Phillips.) Experiments with the composites at RAE have shown that water absorption is not a difficulty and that the fatigue life under various conditions is excellent, the heat build-up during fatigue testing being much less than with glass and other nonconducting fibres. Friction and wear tests carried out at Farnborough have shown that when carbon fibres are incorporated into thermoplastics and thermosetting resins, the coefficient of friction is lowered and the rate of wear enormously reduced. It seems as if a new class of bearing materials has been created. But many other uses for the materials have been uncovered-the Rolls-Royce Company has, for example, used them for very large fan blades in aircraft engines, which have a clear advantage in efficiency over titanium. Aircraft structures, chemical plant, marine uses and space applications were also mentioned.

Considerable increases in the stiffiness of thermoplastics are obtained by incorporating small amount of chopped carbon fibres - for example, 10 per cent weight addition can increase the modulus by 100 per cent. This is important in the manufacture of large mouldings.

Sensible suggestions for further uses of CFRP are welcomed by the Ministry of Technology.

\section{Crack Detector}

THE development of a new instrument for detecting invisible cracks in iron and steel surfaces was announced on Monday by the National Research Development Corporation. The new instrument works on the principle that a coil carrying an alternating current will induce eddy currents in nearby conducting materials. When the coil is moved over a surface crack, the crack causes variations in the eddy currents leading to a charige in the voltage across the coil. This can be detected by a meter or made to sound a warning buzz in an earphone worn by the operator.

Eddy current techniques in non-destructive testing are not new, but up to now they have not been widely applied to ferrous materials. This has been because variations in the distance of the coil from the material under examination, such as might be caused by paint or rust layers, lead to interfering effects. The advantage of the new instrument is that it can be compensated for variations in the gap between the coil and the metal. This means that once the electronic circuit has been balanced for a particular specimen the instrument can be used over rough surfaces which may be covered by paint or rust, and over welds.

The initial impetus for the design of a crack detector was provided by the discovery of cracks in the hull of the nuclear submarine HMS Dreadnought. The instrument was developed by the Admiralty Materials Laboratory at Poole, and the patent rights were assigned to the National Research Development Corporation for exploitation. Two licensees have been appointed to manufacture and sell the instrument.

Because the new detector is simple, portable and rugged, it is likely to find many applications for testing structures in the field. Time savings of more than 80 per cent are expected when compared with conventional magnetic methods of crack detection, which involve cleaning the surface under examination. About 
70 prototype crack detectors made by the Admiralty Materials Laboratory are at present in use in dockyards and research establishments. The new instrument is proving of interest to British Rail, which has recently been seriously troubled by cracks in railway lines. A special version is in the process of development for fitting to railway wagons so that the track can be inspected at high speed.

\section{Scientific Memorabilia}

A PLEA for the preservation of unpublished scientific records, manuscripts and correspondence has been made by the President of the Royal Society and the Master of the Rolls. The Royal Society and the Historical Manuscripts Commission have now formed a standing joint committee under the chairmanship of Sir Harold Hartley with the aim of locating, preserving and making accessible this material. The committee is to prepare and publish a guide to the location and content of the personal papers of leading British scientists and technologists from the sixteenth century until, and including, the time of Lord Rutherford (but excluding scientists still living). The preparation of this guide has been made possible by a grant from the Goldsmiths' Company. The librarian of the Royal Astronomical Society, Dr R. E. W. Maddison, is to be editor. Many of the papers are still in private possession, and Professor Blackett and Lord Denning are appealing to all owners of such papers to write to Dr Maddison (at the Royal Astronomical Society, Burlington House, Piccadilly, London, W1) and to inform him of what they possess. The papers will remain the owner's property-the aim is to locate the papers, to ensure their preservation, and to make them available in original or copy to historians.

\section{New Ways of Making War}

A Two-DAY conference on chemical and biological warfare last week in London served at least as an opportunity for breaking down what Lord Ritchie-Calder, chairman of the conference, described as the conspiracy of silence on the subject. The conference was held under the auspices of the newly formed J. D. Bernal Peace Library, and was attended by scientists and science journalists from several countries. Lord RitchieCalder set the tone for the proceedings with a reminder - culled from the late Professor Joliot-Curie - of how weapons like these might be used without the intended vietims knowing.

A long list of known chemical weapons was provided by Mr J. Perry Robinson. At one end of the spectrum are the so-called riot-control agents-lacrimators and the rest-which seem to be lethal in sufficiently high concentrations. Nettle gases, dichlorformoxime, for example, sting hard. Blood gases such as hydrogen cyanide block oxygen circulation. Vesicants, of which mustard gas is typical, injure all kinds of tissues and can therefore be lethal. Involatility enhances their effectiveness. Then there are nerve gases which inhibit cholinesterase and which are therefore the most rapidly lethal of these agents. Mr Robinson was also able to describe several means by which these agents can be disseminated - one of the essential tricks of the trade. Defence, he said, would probably be too expensive for most countries.
Academician I. Malek from Prague had very little new to say, although he emphasized the self-spreading capacity of biological agents and their cheapness. He argued that the only defence against biological weapons was an international agreement to forbid their use.

The uses of defoliants were also discussed at the meeting, largely because of their use in Vietnam by United States forces. According to Professor Arthur Galston, professor of plant physiology at Yale University, 1,000 square miles of Vietnam were dealt with in this way in the first 9 months of 1966. Dr F. Kahn of the University of Paris held that agents like these can be toxic to human beings - notwithstanding official statements to the contrary. Dr Kahn is a member of a scientific commission set up for the International War Crimes Tribunal which met last year in Stockholm. His evidence for the lethality of defoliants is based on evidence collected orally by a government committee in North Vietnam and experiments carried out with ducks.

Dr J. H. Humphrey, deputy director of the National Institute for Medical Research of the United Kingdom Medical Research Council, had a practical suggestion to make. He argued that there would be great benefit in an arrangement by means of which the research establishments engaged on chemical and biological warfare were to become non-secret places, at least for a trial period. Then, at least, taxpayers would know what was being done with their money.

\section{Listing Overseas Visitors}

DifFicult as it is, tracing the names and numbers of overseas academic visitors at present undertaking research in Britain is not impossible. Two almost up-to-date lists have been compiled for United States and Commonwealth visitors showing where they are and just what they are doing.

The US directory of American university teachers and senior scholars for 1967-68 was prepared by the US Information Service of the American Embassy in London and contains over six hundred names. The present location, field of study, the awards covering the research, and the university or institute which the visitors attended in the US are all quoted. Data are based on information provided by registrars and other officers in British universities and, at this stage, copies are available only to university registrars. (The US Embassy says that it is unable to supply further copies on demand.)

The second list, prepared by the Association of Commonwealth Universities, is based on information furnished by the registrars of member universities and university colleges in overseas parts of the Commonwealth, and of former member universities in the Republic of South Africa. Some 630 visitors are currently in Britain and there is a list of about 360 visitors shortly to arrive; dates of departure are given where known. By circulating copies of the list to universities, learned societies and other interested bodies in Britain, the association hopes that this will assist contact between the members of these bodies and current or prospective visitors.

Although the lists are incomplete, they provide a useful service which could usefully be taken up by countries outside the US and the Commonwealth which also have senior scholars in Britain. 